
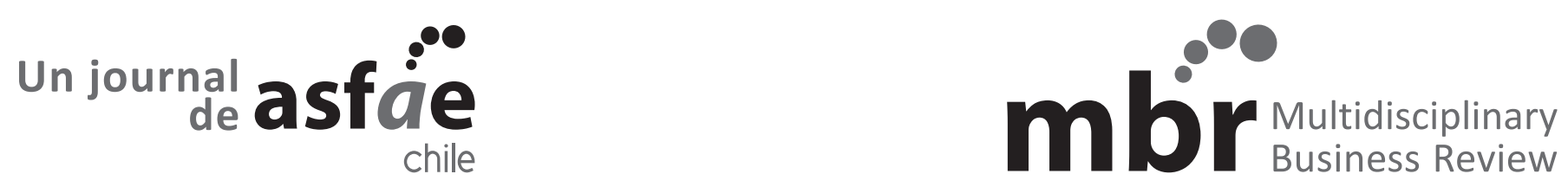

\title{
A VISUAL APPROACH FOR DEVELOPING SOCIAL ENTERPRISES
}

\author{
UN ENFOQUE VISUAL PARA EL DESARROLLO DE EMPRESAS SOCIALES
}

\author{
Sabrina Bresciania* • Martin J. Eppler ${ }^{\mathrm{b}}$ \\ Classification: Conceptual Paper \\ Received: June 30, 2020 / Revised: October 7, 2020 / Accepted: October, 14, 2020
}

\begin{abstract}
The emerging interest in social entrepreneurship is challenged in practice by the complexity of balancing economic and social aspects, and by the difficulties of getting the public to understand the very concept of social enterprising. How can we support social entrepreneurs in developing and growing their organizations? The cognitive advantages of thinking and working visually are well established in the literature, but not yet applied to guide the entire social enterprising process. Mapping and communicating ideas visually can provide several benefits, not only in the ideation phase, but also for managing, optimizing, and growing a social enterprise. We present a framework with visual formats that can be utilized by social entrepreneurs in each specific phase of the social enterprise development: (1) idea generation, (2) social enterprise model refinement, (3) idea promotion and resources acquisition, (4) planning, (5) sales and instructions, (6) scaling impact, and (7) measuring and monitoring. At a theoretical level, the framework aims to structure and summarize the benefits of visual representations of knowledge for the field of social entrepreneurship. This visual approach has practical applications for social entrepreneurs who can utilize it as an overarching tool, for an informed selection and use of visualizations to support the development of their social ventures.
\end{abstract}

Keywords: Social entrepreneurship, visualization, visual maps, social business, canvas, visual techniques, Peru.

\section{Resumen}

El interés emergente por el emprendimiento social se ve desafiado en la práctica por la complejidad de equilibrar los aspectos económicos y sociales, y por las dificultades para lograr que el público comprenda el concepto mismo de emprendimiento social. ¿Cómo podemos ayudar a los emprendedores sociales a desarrollar y hacer crecer sus organizaciones? Las ventajas cognitivas de pensar y trabajar visualmente están bien establecidas en la literatura, pero aún no se aplican para guiar todo el proceso emprendedor social. El mapeo y la comunicación de ideas visualmente pueden proporcionar varios beneficios no solo en la fase de ideación, sino también para administrar, optimizar y hacer crecer una empresa social. Presentamos un marco con formatos visuales que pueden ser utilizados por emprendedores sociales en cada fase específica del desarrollo de la empresa social: (1) generación de ideas, (2) refinamiento del modelo de empresa social, (3) promoción de ideas y adquisición de recursos, (4) planificación, (5) ventas e instrucciones, (6) ampliación del impacto y (7) medición y seguimiento. A nivel teórico, el marco tiene como objetivo estructurar y resumir los beneficios de las representaciones visuales del conocimiento para el campo del emprendimiento social. Este enfoque visual tiene aplicaciones prácticas para los emprendedores sociales que pueden utilizarlo como una herramienta general, para una selección informada y el uso de visualizaciones para apoyar el desarrollo de sus empresas sociales.

Palabras clave: emprendimiento social, visualización, mapas visuales, social business, modelo visual, Perú.

Institute for Media and Communications Management, University of St. Gallen, Switzerland. Email: sabrina.bresciani@unisg.ch Institute for Media and Communications Management, University of St. Gallen, Switzerland. Email: martin.eppler@unisg.ch 


\section{Introduction}

A key research challenge in the domain of social entrepreneurship regards the description and invention of fitting methods that social entrepreneurs can use in their daily activities (Bornstein, 2007). They need versatile and yet cost-effective techniques to support the growth of their social enterprises in the various stages of development. Compared to traditional entrepreneurs, social entrepreneurs face more challenges when developing their organizations (Hynes, 2009), because of the novelty of the field and consequent lack of specific overarching frameworks. In addition, they also encounter greater difficulties in communicating and explaining their social business ideas to the public, since the very concept of social entrepreneurship is not well-known and might even be seen as paradoxical (Leadbeater, 1997). Since Virzia et al., (2015) found that when subjects are more confident, they are more likely to become entrepreneurs, it seems crucial to identify methods that can support potential entrepreneurs in becoming more confident with the social enterprise creation process.

Graphic representations and visual thinking have not yet been systematically applied to support social entrepreneurs in creating, growing and scaling their ventures. In entrepreneurship practice, classic information visualization is used mainly in the last phase of (quantitative) monitoring. But academic literature shows that the potential of visualization for supporting entrepreneurship is even greater when extending the scope of visualization types to knowledge visualization formats (which refer to the visualization of ideas, concepts and procedures). Thus, we propose a framework for structuring and organizing fitting graphic and conceptual representations for the specific phases of social enterprise development. These diverse types of graphic representations can help social entrepreneurs - at the various stages of development of their organizations - strategize and fruitfully communicate with a great variety of stakeholders. In this contribution we aim to show that knowledge visualization can provide versatile and possibly inexpensive ways to augment social entrepreneurs' activities systematically.

After the literature review section, we outline a framework consisting of seven phases of social enterprise development, namely (1) idea generation, (2) social enterprise model refinement, (3) idea promotion and resources acquisition, (4) planning, (5) sales and instructions, (6) scaling impact, and (7) measuring and monitoring. Each of these phases can be supported by specific visualization genres; for instance, idea generation can be facilitated by sketched system diagrams, while measurement and monitoring should be supported by charts and information visualization. The originality of this contribution lies in outlining the potential benefits of visuals for social entrepreneurship - researchers can derive specific propositions from this framework. Social entrepreneurs can utilize the framework as a guide to select the appropriate visual methods for growing or optimizing their ventures. Educators can consider the framework as a potential way to structure project-based social entrepreneurship workshops and courses.

\section{Benefits of Visualizations for Social Enterprises}

Social entrepreneurship recently gained wider attention in academia (Ayob et al., 2016; Dart, 2004; Dacin et al., 2010; López-Gonzáleza et al., 2016; Ridley-Duff \& Bull, 2019; Seelos \& Mair, 2007). A large number of definitions of what is a social enterprise (SE) abound and are still heterogeneous (Defourny \& Nyssens, 2017; Doherty et al., 2014; Ridley-Duff \& Bull, 2019). Within the multiple and varied definitions of what constitutes a social enterprise, in this paper we consider a social enterprise to be a "spectrum of options" (Ridley-Duff \& Bull, 2019, p. 76) "between 'traditional non-profit' and 'traditional for-profit' enterprises" (Ridley-Duff \& Bull, 2019, p. 76, based on Alter, 2007 and Dees, 1998). In fact, social enterprises can be considered hybrid organizational forms (Mair \& Noboa, 2003) that have both an entrepreneurial orientation and a focus on social innovation (Perrini \& Vurro, 2006); it is precisely this hybrid nature aiming for financial sustainability and fulfilling a social purpose that is the defining characteristic of social enterprises (Doherty et al., 2014). The diversity of social enterprise models is inherent in their nature, reflecting the actual diversity of missions (Defourny \& Nyssens, 2017), and can be categorized in four major social enterprise models: the Entrepreneurial Non-profit model, the Social Cooperative model, the Social Business model, and the Public-Sector Social Enterprise model (Defourny $\&$ Nyssens, 2017). For the purpose of this paper we endorse a broad definition, instead of focusing on one specific model of social enterprise, since we aim to develop a widely applicable framework of visual methods that can be deployed by a broad range of social enterprises, from "non-profits with income-generating activities" and "non-profits funded mainly or wholly by market trading" (Ridley-Duff \& Bull, 2019, p. 77, adapted from Alter, 2007), to social businesses (as defined by Yunus, 2009).

Visualization has been successfully utilized in traditional business contexts (Meyer et al., 2013), i. e., for innovation (Tversky \& Suwa, 2009), strategy development (Eppler \& Platts, 2009) and as an investigation method (Bell \& Davison, 2013; Espinozaa \& Cataldob, 2019). 
In parallel, images, mapping techniques, and information visualization have been utilized for social purposes, i. e., for advocacy (Emerson, 2008) and for facilitating intercultural dialogue (Bojer et al., 2008).

Yet, in the field of social entrepreneurship the effectiveness of visual methods or graphic representations are rarely studied (with the notable exceptions of Barberá-Tomás et al., 2019; and Sparviero, 2019), and not yet organized into a comprehensive framework. In the domain of entrepreneurship, Muñoz et al. (2011) found that entrepreneurship students who improved their opportunity-identification mental frames during the course, had a radical shift in the way that they visually represented the concept of entrepreneurship with sketches. Clarke (2001) observed and theorized on how visual symbols are used by entrepreneurs for impression management, in particular to find clients and investors.

Information and knowledge visualization can offer a relevant contribution to social entrepreneurs, not only for impression management (Barberá-Tomás et al., 2019), but more strategically to guide, structure and support their venture creation, evaluation, and development. Social entrepreneurs, particularly in the start-up phase, have a scarcity of resources - visualization can offer a cost-efficient solution for supporting social entrepreneurs in crafting effective messages to stakeholders, partners, and customers, while clarifying ideas through sketching or planning actions. Having identified this gap in the literature, the aim of this contribution is to start bridging the world of graphic representations and knowledge visualization with the field of social entrepreneurship by investigating the following research question: Which types of visual techniques could support the development of social enterprises? To answer this question, we develop an overarching framework for organizing visual technique genres according to the activities carried out by social entrepreneurs. Given the great variety of social enterprises and their different stages of development, we do not provide an all-encompassing framework; specific visual techniques will be useful for different types of social enterprises.

\section{Selecting the Best Visual Methodologies for Each Phase: A Framework}

To be able to answer this research question, we developed a framework with a sequence of seven phases of development of social enterprises in order to propose visualization methods that could be suitable for supporting each specific phase. The methodological approach is similar to the study of Paschen (2017), who provided a "framework for choosing the right crowdfunding type for each stage in the startup life cycle" (p. 179).
Paschen (2017) differentiates three stages of start-ups development, based on the business life cycle framework (Lewis \& Churchill, 1983), (1) the pre-startup stage, (2) the startup stage, and (3) the growth stage. We base our framework on these categories and - since they are rather broad for the purpose of proposing fitting visual methods - we further break them down into more detailed phases based on the known benefits of visualization in management (Eppler \& Bresciani, 2013).

Unlike most processes in extant literature, we do not focus solely on the pre-startup phase, but instead propose to organize visual techniques for the entire life cycle of a social venture. This conceptualization is developed taking the entrepreneurial development process as the unit of analysis. We must, however, recognize that the process of innovation and entrepreneurial creation is cyclical and nonlinear in reality - according to the Design Thinking approach (Brown, 2008) businesses should adopt the methods of designers, taking a holistic human-centred approach to design products, services and experiences. Design Thinking has been considered relevant for social innovation too (Brown \& Wyatt, 2010), since "initiatives falter because they are not based on the client's or customer's needs and have never been prototyped to solicit feedback" (Brown \& Wyatt, 2010, p. 32). We offer here a sequential framework for the sake of exposition clarity; readers can nevertheless use the framework in a nonlinear manner.

At a theoretical level, the purpose of our work is to provide a guiding framework for developing specific propositions to be tested in future research. At a pragmatic level, the framework, presented in Table 1, aims to guide social entrepreneurs in harnessing the advantages of visual techniques in their social venturing process, from idea generation to fundraising and monitoring. The aim of the framework is not prescriptive. Not all visualizations are suitable for all tasks nor for all types of social enterprises: analytical visualizations, such as dashboards or flowcharts, should be employed for analytical phases, while visual metaphors and storytelling should be utilized when addressing the general public and aim to trigger an emotional reaction (Horn, 1998). The most useful visual technique depends on a number of factors, such as the aim of the social enterprise (Ridley-Duff \& Bull, 2019), the target audience, the number of people involved, and the medium of communication (i. e., online or offline).

Next, illustrative examples of visualization methods for each phase of the framework are described.

\section{Idea Generation}

What is represented: the problem and key innovative idea (systemic change or product/service). 
Table 1. A Framework of Visual Methods for Supporting the Development of Social Enterprises

\begin{tabular}{|c|c|c|c|c|c|}
\hline $\begin{array}{c}\text { STAGE } \\
\text { (Paschen, 2017) }\end{array}$ & PHASE & Visual methods & Content & Target audience & Motivation \\
\hline \multirow[b]{2}{*}{ Pre-startup } & 1. Idea Generation & $\begin{array}{l}\text { System thinking, sketches, } \\
\text { creativity templates }\end{array}$ & $\begin{array}{l}\text { Problem and key } \\
\text { innovative idea }\end{array}$ & Entrepreneurs & $\begin{array}{l}\text { To understand and } \\
\text { ideate collaboratively }\end{array}$ \\
\hline & $\begin{array}{l}\text { 2. Social Enterprise } \\
\text { Model Refinement }\end{array}$ & $\begin{array}{l}\text { Templates, i. e. the Social } \\
\text { Enterprise Model Canvas }\end{array}$ & Key idea in context & $\begin{array}{l}\text { Entrepreneurs and } \\
\text { consultants or partners }\end{array}$ & $\begin{array}{l}\text { To make the innovation } \\
\text { structured and } \\
\text { comprehensive }\end{array}$ \\
\hline \multirow{3}{*}{ Startup } & $\begin{array}{l}\text { 3. Idea Promotion and } \\
\text { Resources Acquisition }\end{array}$ & $\begin{array}{l}\text { Scenario drawings and } \\
\text { infographics }\end{array}$ & Benefits of the offering & $\begin{array}{l}\text { Partners, } \\
\text { stakeholders, investors }\end{array}$ & $\begin{array}{l}\text { To explain and for } \\
\text { impression management }\end{array}$ \\
\hline & 4. Planning & Timelines and Gantt chars & $\begin{array}{l}\text { Rollout steps for the } \\
\text { development of the idea }\end{array}$ & $\begin{array}{l}\text { Entrepreneurs, co-workers } \\
\text { and partners }\end{array}$ & $\begin{array}{l}\text { To forecast and } \\
\text { coordinate work }\end{array}$ \\
\hline & 5. Sales and Instructions & $\begin{array}{l}\text { Storyboards, infographics, } \\
\text { diagrams, objects, } \\
\text { simulations }\end{array}$ & $\begin{array}{l}\text { Benefits of the innovation } \\
\text { and instructions }\end{array}$ & $\begin{array}{l}\text { (Potential) } \\
\text { beneficiaries, users, and } \\
\text { customers }\end{array}$ & $\begin{array}{l}\text { To communicate clearly } \\
\text { to non-experts }\end{array}$ \\
\hline \multirow{2}{*}{ Growth } & 6. Scaling impact & $\begin{array}{l}\text { Diagrams, videos, and } \\
\text { visual storytelling }\end{array}$ & $\begin{array}{l}\text { (Potential) } \\
\text { developments } \\
\text { and achievements }\end{array}$ & $\begin{array}{l}\text { Public, partners, media, } \\
\text { second-tier investors }\end{array}$ & $\begin{array}{l}\text { To create appealing } \\
\text { visuals that can go viral }\end{array}$ \\
\hline & $\begin{array}{l}\text { 7. Measuring and } \\
\text { Monitoring }\end{array}$ & $\begin{array}{l}\text { Charts, dashboards, } \\
\text { assessment templates }\end{array}$ & $\begin{array}{l}\text { Numbers related to } \\
\text { the venture's social } \\
\text { performance }\end{array}$ & $\begin{array}{l}\text { Managers, investors, and } \\
\text { entrepreneurs }\end{array}$ & $\begin{array}{l}\text { To visualize data for } \\
\text { assessment }\end{array}$ \\
\hline
\end{tabular}

Target group: entrepreneur(s).

How it is visualized: with system thinking diagrams, conceptual and/or representational hand drawings, and creativity templates.

The idea generation phase is the first step in creating social change, in which the entrepreneur(s) develops an innovative concept for solving a social problem, which can be a product (or service) as well as a way to improve a system. The pre-requisite for developing a solution is to fully and deeply understand the problem, a principle outlined by Papi-Thornton (2016) and applied at Oxford University's Skoll Centre for Social Entrepreneurship. Since the solution and the problem space co-evolve (Dorst \& Cross, 2001), this first phase entails two strongly interconnected objectives: understanding the problem and ideating solutions.

To understand the problem and the potential implications of an innovation, system thinking diagrams (Checkland, 1999) can be particularly useful in social entrepreneurship (Papi-Thornton, 2016) because meaningful impact is often achieved with systemic change. Mapping the system visually with system mapping can provide support in order to understand a system, the multiple actors involved, and their interconnections. This is an important pre-requisite for developing ideas on how to act upon a system and to discuss problems and solutions with other actors or stakeholders. System mapping techniques specifically addressing social impact have been developed by System-led Leadership (http:// systems-ledleadership.com/) and Disrupt Design (www. disruptdesign.co/). Figure 1 provides an example of the system mapping approach utilized to understand the systematic relations between violence, colonialism, and the exploitation of women in Papua (Source: https://mapthesystem.sbs.ox.ac.uk/article/women-violence-and-modern-slavery-in-papua-university-of-oxford).

System mapping can be particularly useful for social enterprises to explore collaborations, as identified by Ayob et al., (2016) through a review of the literature, social innovation involves new forms of collaborations (Shepherd, 2020) with new and less hierarchical relationships which in turn lead to empowerment. In relation to this aspect, entrepreneurs can find it useful to utilize templates for making their theory of change explicit (Organizational Research Services, 2004), such as the "Theory of change" canvas developed by the Innovation Foundation Nesta (https://diytoolkit.org/tools/theory-of-change/) with the purpose of creating a roadmap with steps for achieving a social goal, or the visual template created by NEF Consulting (https://www.nefconsulting.com/ our-services/evaluation-impact-assessment/prove-andimprove-toolkits/theory-of-change/), among others.

While verbal and textual information is abstract, visualization makes concepts more concrete and thus manageable. In this phase of divergent thinking, it is important for the entrepreneur to illustrate the system and the innovative idea in a format that looks provisional, for instance, by drawing on a whiteboard, or using pencils and paper. The provisional appearance invites contributions and modifications that support refining and improving the idea (Bresciani, 2019). Sketching the main idea is also useful for discussing it with partners and collaborators, who can more easily see the key innovation and contribute to the development of the concept. 
Figure 1. Causal Loops Map of the Project "Women, Violence and Modern Slavery in Papua", winner of the 2019 Map the System Competition

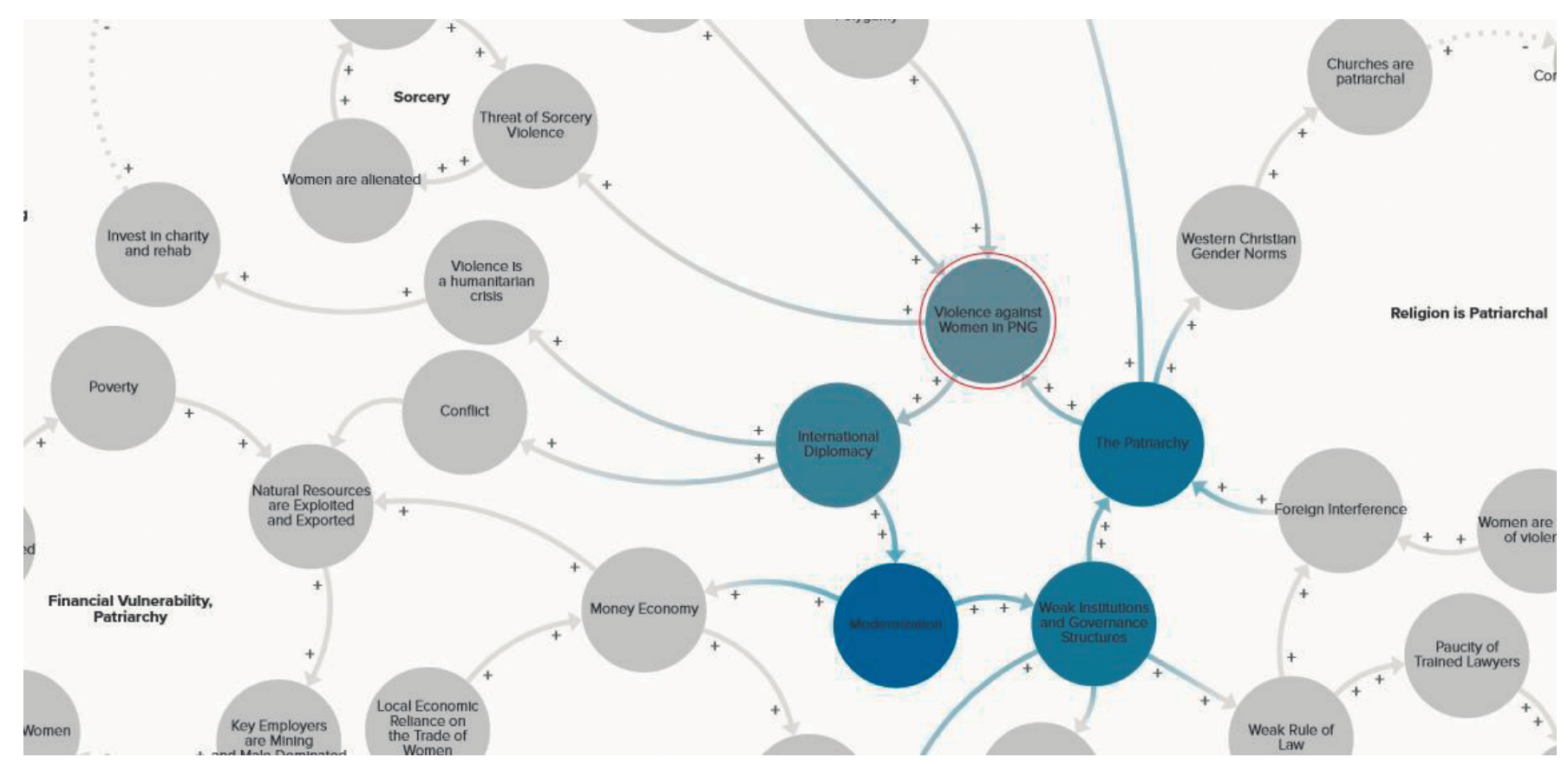

Source: interactive map available at https://embed.kumu.io/fe1f71110c7ac139545b6d80349b5921\#map-the-system-modern-slavery-in-papua-new-guinea/violence-against-women-in-png

The graphic representation of the social innovation needs to be easy to change and invite modifications. For this reason, images should have low perceived finishedness (Bresciani, 2019): they should look provisional, unfinished, and modifiable. Conversely, if in the idea generation phase, the visual representation of the product or service is presented in a polished and refined format (i. e., in a slideshow presentation), collaborators and observers will be less willing to give feedback, comments or to contribute to the idea development (Bresciani, 2019; McGrath et al., 2016). Yet, the process of creativity should be guided: specific visual templates can direct social entrepreneurs toward more focused ideation sessions (Alexander et al., 2015). Several visual creativity techniques can be deployed for this purpose, such as the concept fan method (DeBono, 2015) or the Paths to Success method (Pfister \& Eppler, 2012).

\section{Social Enterprise Model Refinement}

What is represented: the key idea in context.

How it is visualized: with templates; i. e., the Social Enterprise Model Canvas (Sparviero, 2019).

Target group: the entrepreneur(s) and consultants or partners.

Once the main idea or product has been defined, it should be considered in the larger context in which it is embedded: analytical templates and canvases can support entrepreneurial reasoning in this phase.

The Business Model Canvas, developed by Osterwalder and Pigneur (2010), is a very widely utilized visual template for developing the business model of an organization (Fig. 2). The canvas is typically used as a large poster with sticky-notes, or within a software application. It helps entrepreneurs consider the business context through nine major building blocks (i. e., customer segments, key resources, costs, partners, etc.). Defining the business model is a complex task carried out by a small group of founders, or with the help of consultants and partners. The Business Model Canvas is used in workshops for developing social businesses, and the template is freely available online. Several adaptations of the Business Model Canvas specifically focused on social impact have been created, such as the Social Lean Canvas (https:/canvanizer.com/new/social-lean-canvas which is an adaptation of the Business Model Canvas with the addition of purpose and impact), and the Mission Model Canvas developed by Steve Blank in collaboration with Osterwalder (https://steveblank.com/2016/02/23/the-mission-model-canvas-an-adapted-business-model-canvas-for-mission-driven-organizations/).

An academically grounded modification of the Business Model Canvas is the "Social Enterprise Model Canvas (SEMC), a Business Model Canvas (BMC) conceived for designing the organizational settings of social 
enterprises, for resolving the mission measurement paradox, and for meeting the strategy, legitimacy and governance challenges" (Sparviero, 2019, p. 232). The Social Enterprise Model Canvas is not simply an adaptation of the Business Model Canvas; the methodology, rather than the canvas, has been utilized as a blueprint for developing a new canvas built on academic literature and comprised of 14 building blocks which are specific to addressing the typical tensions of hybrid organizations; i. e., in combining market and social values (Sparviero, 2019).

The use of templates in this phase is useful to give a structure to the initial business idea, thus developing it further in a systematic manner. Secondly, the pre-defined categories of templates provide entrepreneurs with a comprehensive categorization of the contextual factors to consider (i. e., the legal choices, ICT choices, etc. as outlined in a model created by FairShares Association http://www. fairshares.coop/fairshares-model/). However, if business model templates are used too early (in the idea generation phase), they could negatively constrain creativity and innovation.

Figure 2 shows the business model designed by a group of MBA students participating in a social entrepre- neurship course who ideated high quality affordable daycare for children in Peru.

\section{Idea Promotion and Resources Acquisition}

What is represented: benefits of the offering.

How it is visualized: with scenario drawings, infographics.

Target group: partners, investors.

After having defined the idea and the business model, social entrepreneurs face the hard task of securing resources or funds to start the venture. The goal of this phase is to explain the benefits and the principles of the social innovation to partners or investors, and to convince them of the benefits of the social innovation. In this phase they can rely on impactful visualizations such as quasi-realistic scenario drawings, infographics or vivid images and visual metaphors. It is challenging to explain innovative ideas to non-technical public; visual symbols used by activists (Barberá-Tomás et al., 2019) and entrepreneurs (Clarke, 2001) are found to mobilize and energize volunteers, clients, and investors.

In comparison to analytic visualization, such as the canvas seen in the second phase (Fig. 2), quasi-realistic

Figure 2. Example of the Application of the Business Model Canvas (Osterwalder \& Pigneur, 2010)

for Designing the Business Model of a High Quality Affordable Daycare

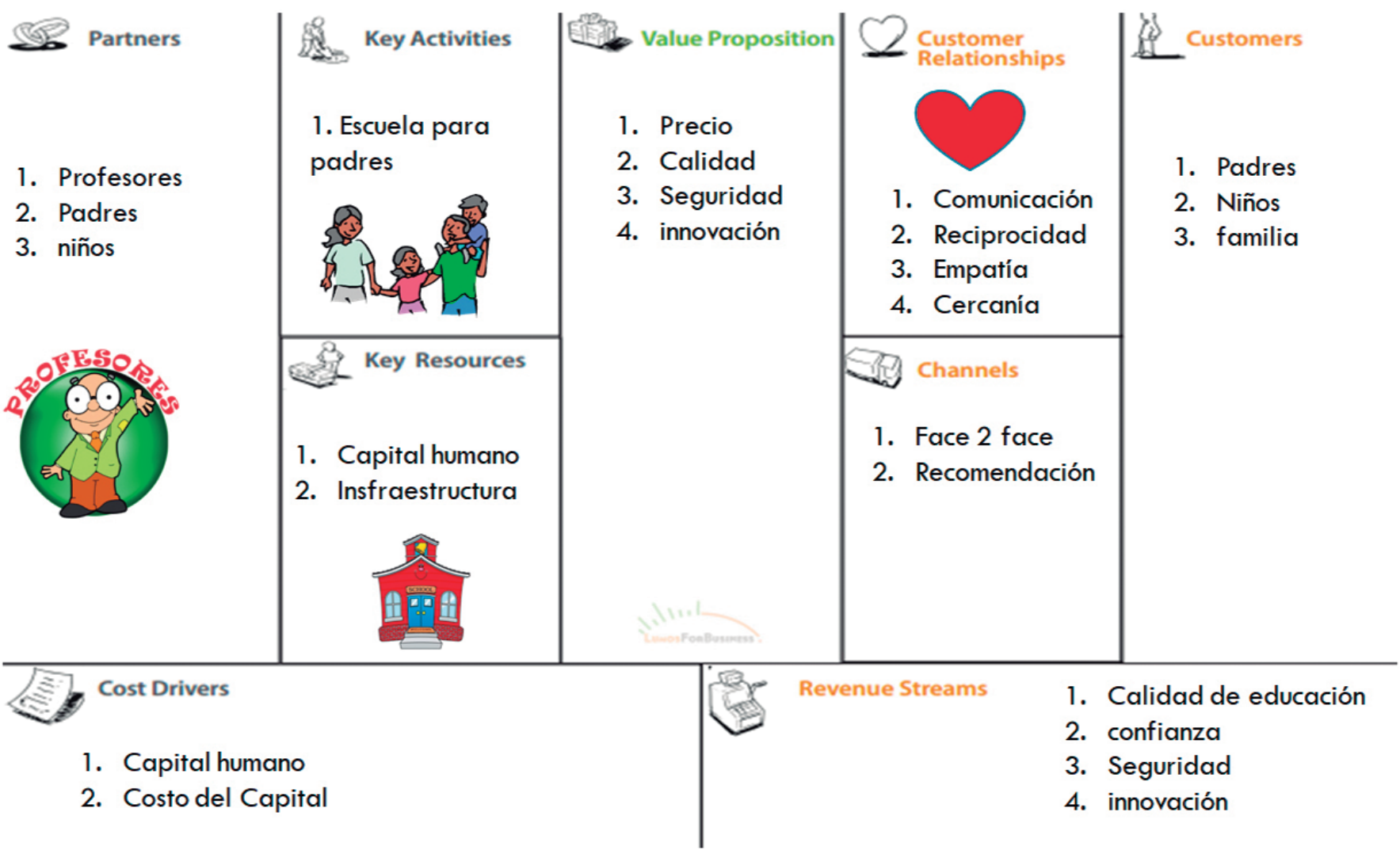


visual explanations prompt emotional responses from the audience. An example of a conceptual scenario can be seen in Figure 3, created by a group of participants in an executive course on social entrepreneurship: the participants aimed to develop a social enterprise that could serve as a link to connect remote communities that are hardly accessible. The complex entrepreneurial idea of acting as a bridge between remote communities and potential investors is visualized with quasi-realistic images which show at the same time the sequence of steps to carry out the objectives of the social enterprise, as well as the interconnections between actors.

\section{Planning}

What is represented: rollout steps for the development of the idea.

How it is visualized: with timelines and Gantt charts.

Target group: entrepreneur(s), co-workers and partners.

When resources are secured, a systematic plan of actions for the enterprise should be developed based on the available resources. The most appropriate visual formats for this phase are timelines and Gantt charts. Time is typically depicted horizontally, from left to right (in Western cultures). Conversely, in the vertical axis of the visualization, a number of different actors or action streams can be displayed (Yakura, 2002).

While most well-established organizations find it useful to deploy precise timelines or utilize project planning software for coordinating projects among a large number of collaborators, new ventures can find it more useful to have flexible timelines that can be easily modified as new needs and scenarios emerge. In Figure 4 we can see an example of a timeline created for developing the project of an educational centre in rural Thailand. Participants annotated all useful tasks for creating and promoting the educational centre; however, since the social enterprise does not have the resources to develop all potentially useful tasks, participants were asked to vote (with arrowshaped sticky notes) for the key tasks to be implemented. This visual voting method can save time in meetings instead of having to discuss all ideas - and is very democratic by offering a quick visual insight on the most voted ideas (Phaal et al., 2004).

\section{Sales and Instructions}

What is represented: benefits of the innovation and instructions for its use.

How it is visualized: with storyboards, infographics, diagrams, real life objects, simulations.

Figure 3. Conceptual Scenario of the Social Enterprise "Build-a-Town" Which Aims to Be the Bridge Between Remote Communities and Investors

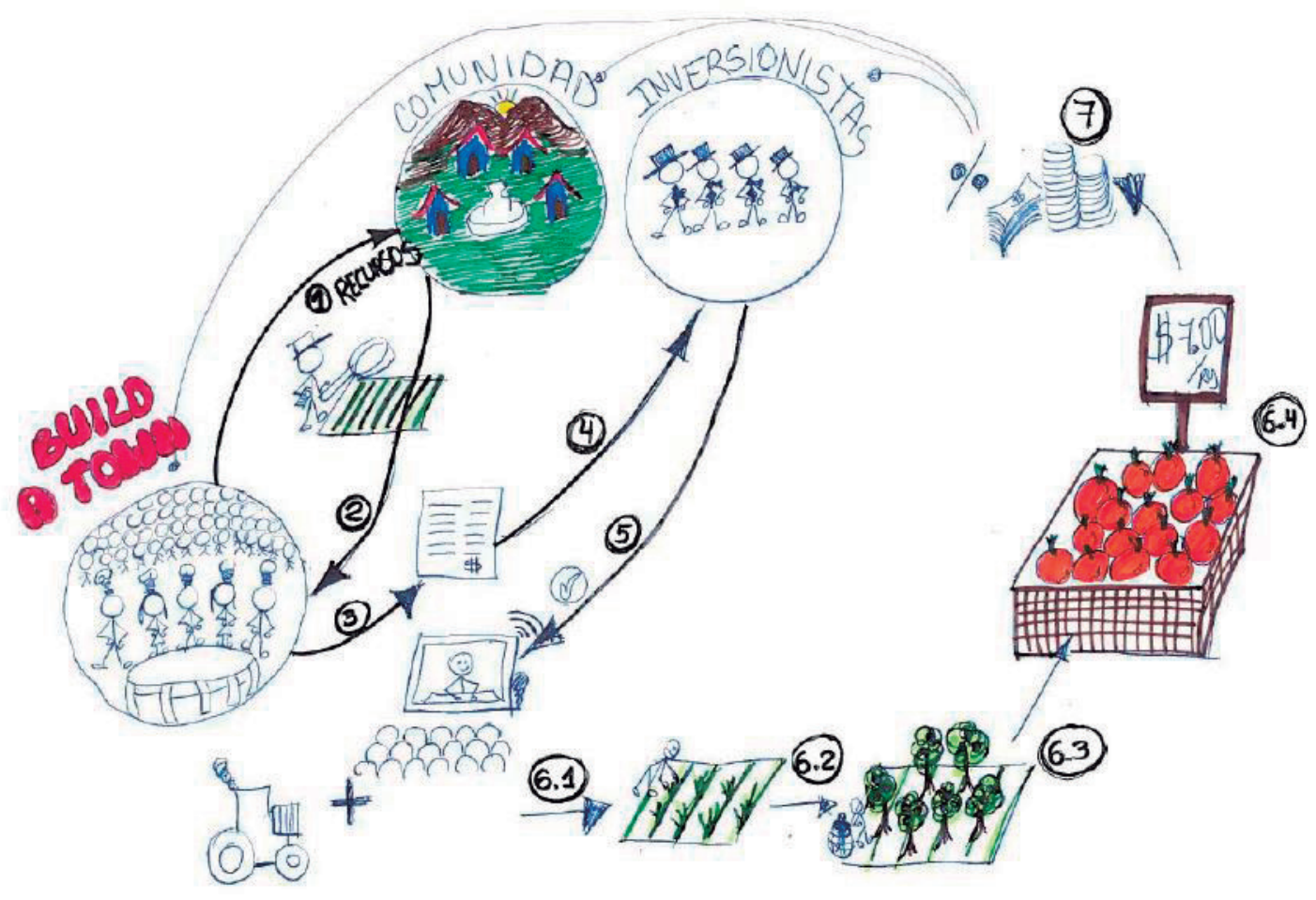


Figure 4. Example of a Timeline for Developing an Educational Centre

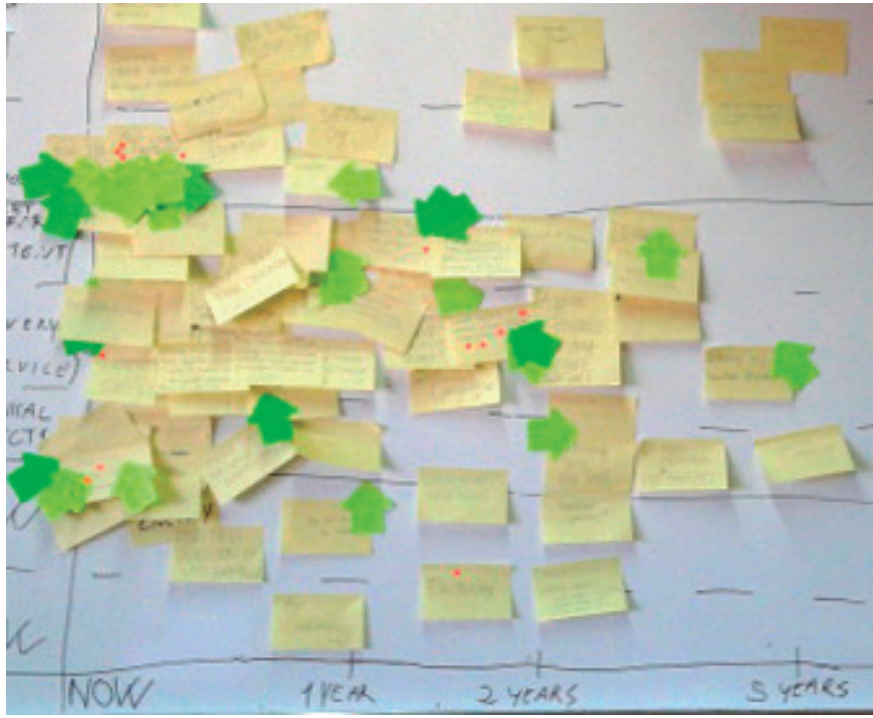

Target group: (potential) users, beneficiaries, customers.

The benefits of a social innovation should be explained to beneficiaries and partners in a clear and engaging manner. Storyboards, infographics, pictures, real objects and interactive simulations are effective visual means for showing end users the benefits that an offering provides and how it works. The customers or beneficiaries of social enterprises often (but not always) belong to the so-called base of the pyramid segment (London et al., 2010; Prahalad, 2006); hence, low levels of literacy are typical thus instructions and product explanations should be exemplified with visual (rather than written or verbal) material and interactive games (Gravoso \& Stuart, 2000).

Examples of applications can be seen in the communication of the social enterprise X Runner based in Lima, Peru. The organization's mission is to bring reliable and environmentally friendly sanitation to households that do not have a toilet. To promote their product, they physically bring the product (a toilet), as can be seen in Figure 5 . The product display is complemented by infographics, such as the poster displayed in Figure 6, which explains the uniqueness of their model based on human- and environment-centred-design.

\section{Scaling Impact}

What is represented: (potential) developments, achievements, and impact scaling mechanisms.

How it is visualized: with diagrams, videos, and visual storytelling.

Target group: public, media, partners, second-tier investors.
Figure 5. X Runner Product Display

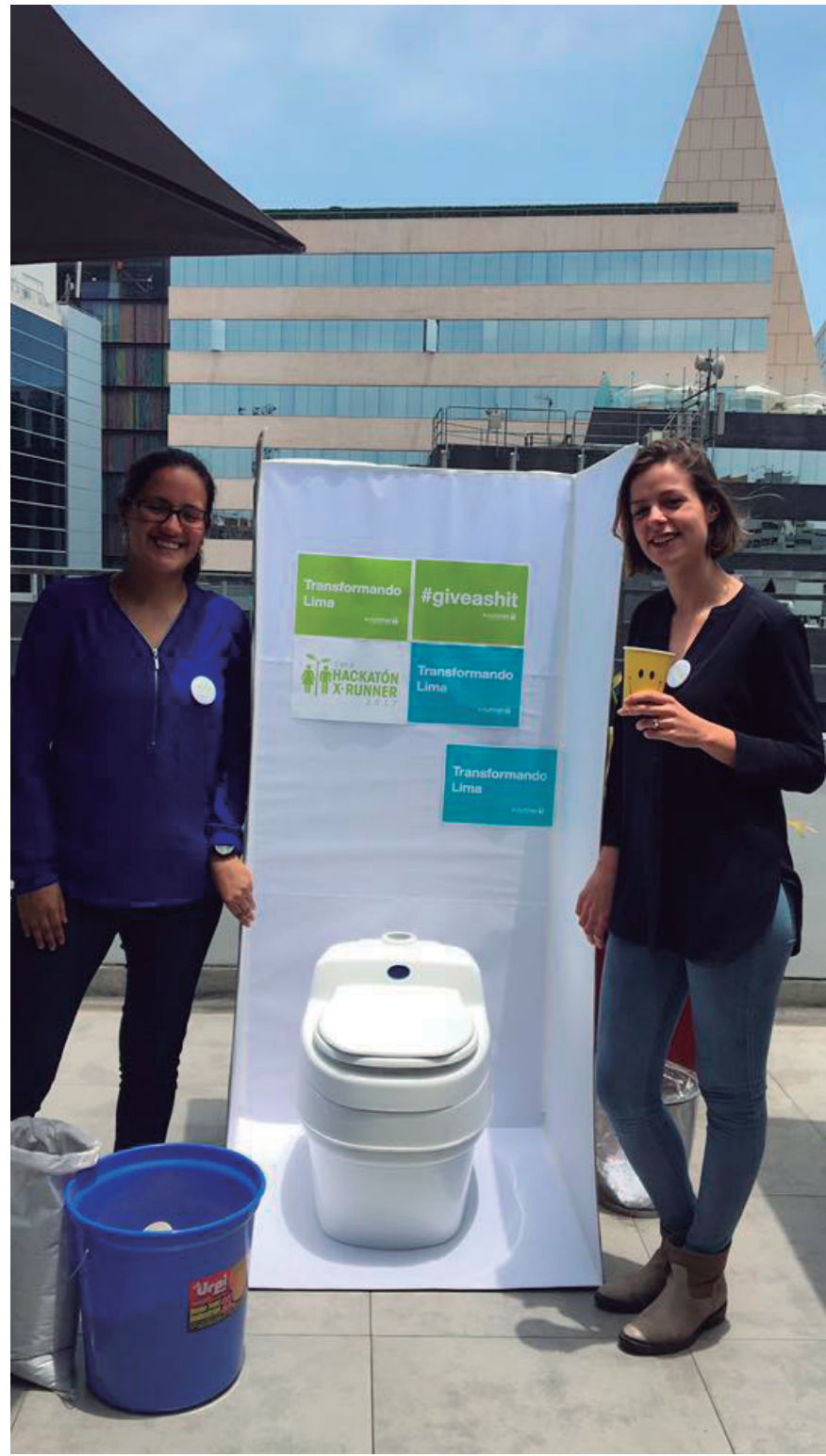

Source: https://www.facebook.com/xrunner.venture/

In contrast to the classic approach of most for-profit businesses, social entrepreneurs aim to scale their impact rather than their financial returns (Haynes, 2009; Ridley-Duff \& Bull, 2019).

For this reason entrepreneurs seek exposure to a large audience, to enlarge the impact of their social innovation. Visualization has the power to easily attract attention and trigger emotional responses in the audience. Visual storytelling is an appropriate method for this phase of growth, targeting a generic public. Videos and presentations can easily reach a vast audience through social media platforms, such as YouTube, Facebook, Intagram, Pinterest or webpages created with an interactive visual storytelling approach (with 'Shorthand' or similar services). An 


\section{¿Cómo funciona nuestro modelo?}

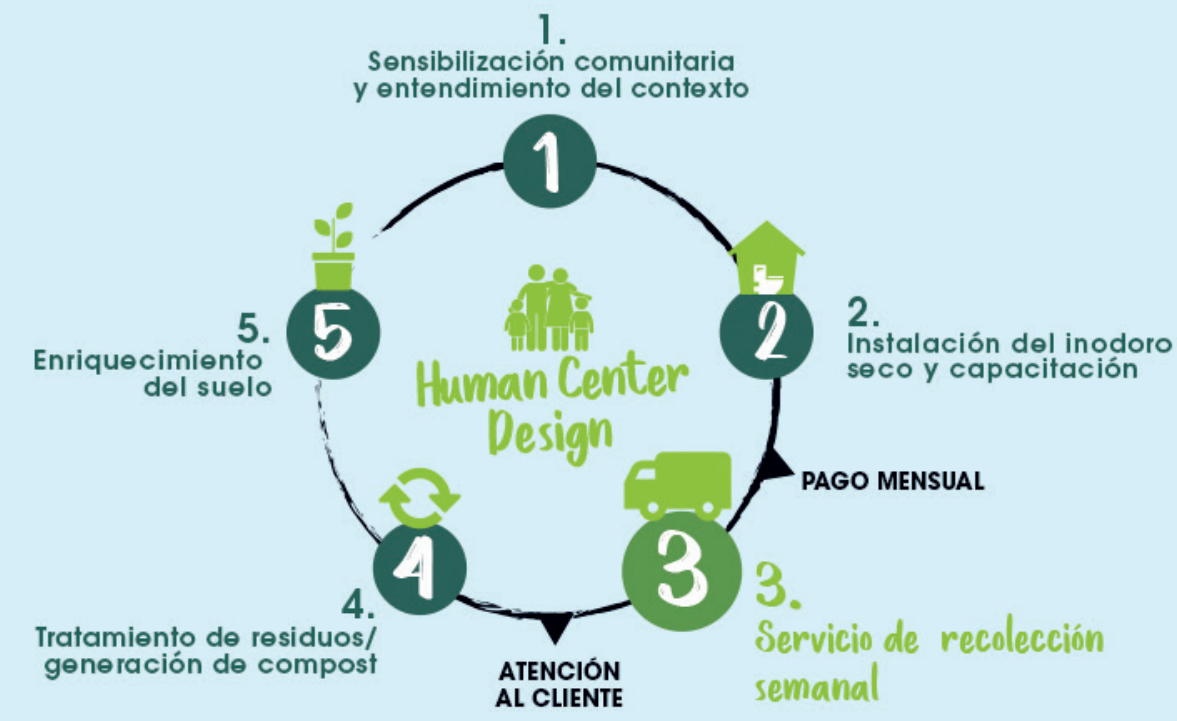

Source: https://www.facebook.com/xrunner.venture/

effective visual story creates interest, triggers emotions, and motivates viewers to inform others about it. Its effectiveness is amplified by online and off-line media, creating a ripple effect (Aaker \& Smith, 2010).

This method has been successfully used to scale up awareness in social campaigns. An emblematic case is Kiva (kiva.org), the world's first online lending platform, which connects online lenders to entrepreneurs (Mittelman \& Rojas-Méndez, 2013). To show the amazing progresses of the social enterprise over time, with the aim to build trust in the organization, Kiva created a video based on information visualization that shows both the mechanism of micro-lending and the vastness of Kiva operations (Fig. 7).

The aim of deploying visuals in this phase is to use a clearly understandable pictorial language (rather than a technical description) that can create an emotional appeal and has the potential to go viral on social media, thus attracting the attention of the media.

\section{Measuring and Monitoring}

What is represented: numbers related to the venture's social impact performance.
Target group: managers, investors, and the entrepreneur(s).

How it is visualized: charts, dashboards, assessment templates.

A key task to assess the delivered impact and keep improving organizational efficiency is to monitor performance. Data can be collected and visualized through interactive tools. In this phase, the visualization's added value is to assess the social impact created, and to simplify the interpretation of large amounts of data. Charts, tables, and various forms of information visualization can be used to visualize organizational performance, and thus see where the biggest impacts are achieved, or where a change in operations is needed. Dashboards (Few, 2006) help managers, investors and partners in monitoring results and support the development of strategic decisions.

Which data should be assessed, and therefore visualized, is not a trivial decision for social enterprises. Generic dashboards and scorecards used by traditional businesses are not suitable for social enterprises, because only the financial aspect is usually emphasized, while social entrepreneurs also need to monitor a number of social outcomes. Mair and Sharma (2012) provided an extensive discussion on the topic of monitoring social enterprises. Haynes (2009) reported that, in general, 


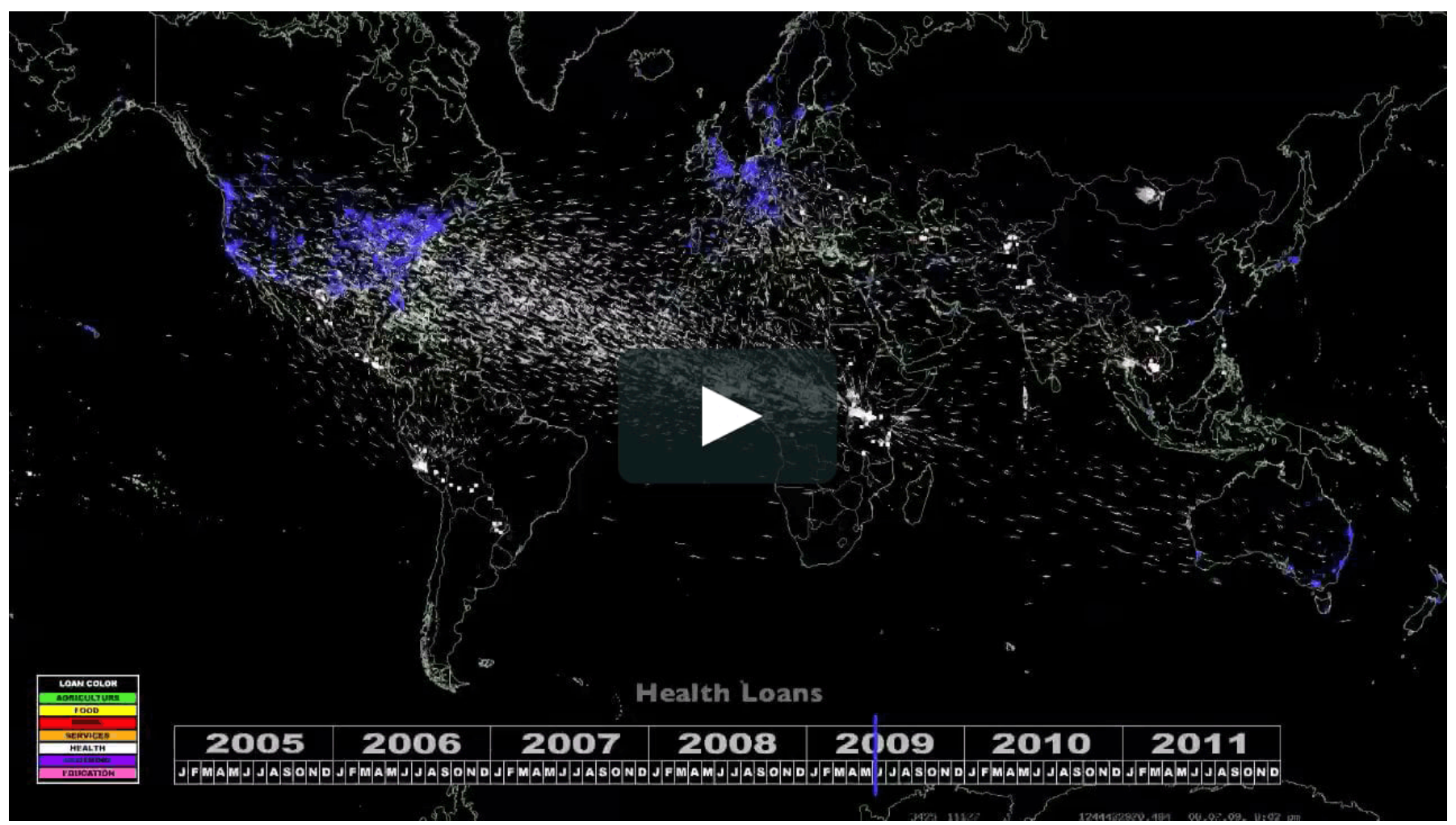

Source: http://www.youtube.com/watch?v=n1V9jVtssfw

social enterprises assess their own performances based on external stakeholder perspective.

Social Return on Investment (SROI) is a widely utilized and standardized method for measuring impact beyond financial returns (Flockhart, 2005). Yet, practical difficulties hold back organizations from deploying this standardized method because it is too generalist and time consuming (Arvidsonetal., 2013; Millar \& Hall, 2013). For this reason, as reported by Millar and Hall (2013), most organizations find it more relevant to utilize internal and customized tools.

Table 2 offers an example of a triple bottom line scorecard, that social enterprises can customize and deploy to monitor their performances regarding economic, environmental, and social measures. This format emphasizes that impact for this organization is expected at all three levels, thus supporting and structuring strategic decision making by organizing relevant indicators systematically.

In this phase, charts and data visualizations are suitable formats to report relevant data and quantitative indicators. On the contrary, employing other visualization formats such as sketchy visuals or storyboards in this phase will not help managers or investors understand the data and will also be perceived as an attempt to mislead (Tufte, 1997).

\section{Implications, Limitations, and Future Research}

The aim of this contribution is to enrich the social entrepreneurship literature with insights from the realm of visual representations used in management, by providing an overarching framework for organizing visual techniques according to phases of the social enterprise development cycle. In social entrepreneurship practice, visual templates (also called canvases or models) are popular visual methods utilized in the pre-entrepreneurship phase by social innovators (i. e., Sparviero, 2019), but academic research assessing the benefits provided by templates is limited. Future research should thus study and compare the performance of the proposed visual methods. Such investigation would be relevant to extend the application of the theory of cognitive fit (Vessey, 1991) to the context of social entrepreneurship: "The theory of cognitive fit suggests that the efficiency and effectiveness of the problem solution depends on a fit between the problem representation and the problem-solving task" (Kelton et al., 2010, p. 81).

According to Kelton et al. (2010, p. 81) "how information is presented affects how information is processed in working memory and the decision processes used to arrive at a decision outcome (Vessey, 1991)". In fact, the use of visual techniques is not free of risks (Bresciani \& 
Table 2. A Triple Bottom Line Scorecard

\begin{tabular}{|c|c|c|c|c|c|}
\hline & & \multicolumn{2}{|c|}{ Operational Performance } & \multicolumn{2}{|c|}{ Intelligence Performance } \\
\hline & & $\begin{array}{l}\text { Business } \\
\text { Processing }\end{array}$ & $\begin{array}{l}\text { Business } \\
\text { Management }\end{array}$ & $\begin{array}{l}\text { Knowledge } \\
\text { Processing }\end{array}$ & $\begin{array}{l}\text { Knowledge } \\
\text { Management }\end{array}$ \\
\hline \multirow{2}{*}{$\begin{array}{l}\text { Social bottom } \\
\text { line }\end{array}$} & $\begin{array}{l}\text { Internal } \\
\text { stakeholders }\end{array}$ & & & & \\
\hline & $\begin{array}{l}\text { External } \\
\text { stakeholders }\end{array}$ & & & & \\
\hline \multirow{2}{*}{$\begin{array}{l}\text { Environmental } \\
\text { bottom line }\end{array}$} & $\begin{array}{l}\text { Internal } \\
\text { stakeholders }\end{array}$ & & & & \\
\hline & $\begin{array}{l}\text { External } \\
\text { stakeholders }\end{array}$ & & & & \\
\hline \multirow{2}{*}{$\begin{array}{l}\text { Economic } \\
\text { bottom line }\end{array}$} & $\begin{array}{l}\text { Internal } \\
\text { stakeholders }\end{array}$ & & & & \\
\hline & $\begin{array}{l}\text { External } \\
\text { stakeholders }\end{array}$ & & & & \\
\hline
\end{tabular}

Eppler, 2015), and entrepreneurs should be made aware of the need to select a suitable visualization method for each specific organizational task. For instance, analytical diagrams are suitable for analytical tasks which require rational argumentation and decision making, as in the second phase of social enterprise model refinement. In contrast, when addressing potential customers, emotional formats are more suitable. If an analytic or complex image is used to communicate the benefits of the product to the general public, its effectiveness will probably be low and thus the time and effort invested in the creation of the visualization will have been wasted.

Social entrepreneurs can utilize the framework to find guidance when selecting suitable visual representations in order to support their work at the different stages of development of their social ventures. In the pre-startup phase, visual guidance can increase potential entrepreneurs' understanding of the system, and therefore, their self-confidence in actually starting a new venture (Virzia et al., 2015). In the startup and in the growth phase, visualization can provide a versatile and affordable way to systematically augment the activities of the organization, optimizing the investment of their often limited resources. Large and long-established companies can count on big advertising budgets, with which nascent social enterprises cannot compete. To overcome this problem, social entrepreneurs can for instance exploit the core advantages of visualization in attracting attention, and spreading the visual message through social media (in which images are shared ten times more than text and links, according to Neher, 2013).

In addition, social enterprises operating with customers or partners who have a low literacy level can communicate the value of their products or the dynamics of their services with visuals to increase understanding (Gravoso \& Stuart, 2000) and recall (Snodgrass \& Vanderwart, 1980).

Social entrepreneurs often need to communicate their innovative business concepts to a variety of stakeholders such as impact investors, foundations, customers, press, and governments. This extreme diversity of stakeholders, due to the hybrid nature of social enterprises that operate at the interface of classic for-profit business and civil society, makes communicating the organization's activities challenging. Visual representations can be deployed to bypass differences in terminology, expressions and even languages, which is particularly relevant for social enterprises operating with a multicultural audience or at an international level. In conclusion, the ambition of the framework is to provide an initial tool for an informed selection and use of visualizations to improve social enterprise effectiveness.

Finally, the framework could be utilized for educational purposes; for example, Figure 8 represents the overview of a presentation of the social entrepreneurship MBA course given at a university in Peru.

\section{Concluding Remarks}

Visualization has proven useful to support businesses in a variety of different domains and tasks, from strategy development or meeting facilitation, to internal communication and customers' interaction. The aim of this work was to start transferring the known benefits of visualization to the specific context of social enterprises. In fact, social entrepreneurs have an even greater need - compared to traditional entrepreneurs - to clearly explain 
Figure 8. Overview of A Social Entrepreneurship Course Presentation Based on the Framework

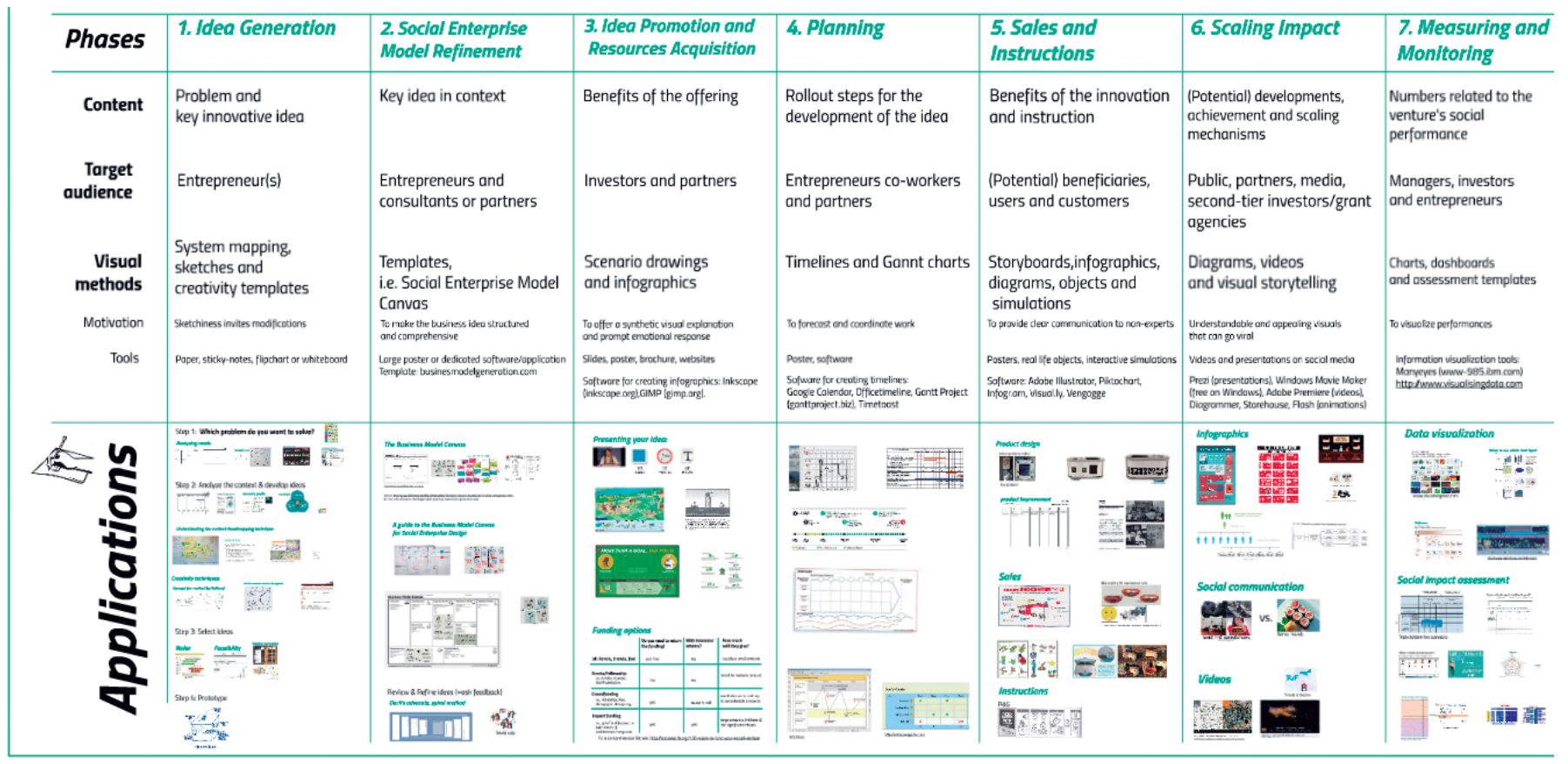

their mission, purpose, and philosophy, as the concept of social entrepreneurship is not yet well-known by the population at large (Yunus, 2009). For this reason, we propose a framework for organizing visual technique genres according to typical phases of social enterprise development, that can function as groundwork guidance for researchers and social entrepreneurs. Because of the novelty of the topic, this work is not free of limitations: the match of visual technique genres to phases of the social entrepreneurship development are based on the scant evidence available. Specific visual methodologies might be suitable only for certain types of social enterprises (Defourny \& Nyssens, 2017). Despite the limitations of this work, partly due to the novelty of the topic in the visualization field, we believe that the proposed framework can provide a first contribution to practice, by helping social entrepreneurs to leverage the benefits of visualization for making a positive social impact. It can contribute to theory, by starting to extend the application of visual representations to the novel and important field of social entrepreneurship, which has the potential to be one of the most important sources of innovation in order to tackle complex and pressing social problems (Leadbeater, 1997).

\section{References}

Aaker, J., \& Smith, A. (2010). The dragonfly effect: Quick, effective, and powerful ways to use social media to drive social change. Jossey-Bass
Alexander, E., Bresciani, S., \& Eppler, M. J. (2015). Understanding the impact of visual representation restrictiveness on experience sharing: An experimental assessment. Journal of Visual Languages \& Computing, $31,30-46$.

Alter, K. (2007). Social enterprise typology. Virtue Ventures $L L C, 12(1), 1-124$.

Arvidson, M., Lyon, F., McKay, S., \& Moro, D. (2013). Valuing the social? The nature and controversies of measuring social return on investment (SROI). Voluntary Sector Review, 4(1), 3-18.

Ayob, N., Teasdale, S., \& Fagan, K. (2016). How social innovation 'came to be': Tracing the evolution of a contested concept. Journal of Social Policy, 45(4), 635-653.

Barberá-Tomás, D., Castelló, I., De Bakker, F. G., \& Zietsma, C. (2019). Energizing through visuals: How social entrepreneurs use emotion-symbolic work for social change. Academy of Management Journal, 62(6), 1789-1817.

Bell, E., \& Davison, J. (2013). Visual management studies: Empirical and theoretical approaches. International Journal of Management Reviews, 15(2), 167-184.

Bojer, M., Roehl, H., Knuth-Hollesen, M., \& Magner, C. (2008). Mapping dialogue. Essential tools for social change. Taos Publishing.

Bornstein, D. (2007). How to change the world: Social entrepreneurs and the power of new ideas. Oxford University Press. 
Bresciani, S., \& Eppler, M. J. (2015). The pitfalls of visual representations: A review and classification of common errors made while designing and interpreting visualizations. Sage Open, Published 14 October 2015.

Bresciani, S. (2019). Visual design thinking: A collaborative dimensions framework to profile visualisations. Design Studies, 63, 92-124,

Brown, T., \& Wyatt, J. (2010). Design thinking for social innovation. Stanford Social Innovation Review, 8(1), 30-35.

Brown, T. (2008). Design thinking. Harvard Business Review, 86(6), 84.

Checkland, P. (1999). Systems thinking. In W. Currie \& B. Galliers (Eds), Rethinking Management Information Systems: An Interdisciplinary Perspective, p. 45-56.

Clarke, J. (2001). Revitalizing entrepreneurship: How visual symbols are used in entrepreneurial performances. Journal of Management Studies, 48(6).

Dacin, P., Dacin, M., \& Matear, M. (2010). Social entrepreneurship: Why we don't need a new theory and how we move forward from here. Academy of Management Perspectives, 24(3), 37-57.

Dart, R. (2004). The legitimacy of social enterprise. Nonprofit Management \& Leadership, 13(4).

De Bono, E. (2015). Serious Creativity: How to be creative under pressure and turn ideas into action. Random House.

Dees, J. G. (1998). Enterprising nonprofits: What do you do when traditional sources of funding fall short. Harvard Business Review, 76(1), 55-67.

Defourny, J., \& Nyssens, M. (2017). Fundamentals for an international typology of social enterprise models. VOLUNTAS: International Journal of Voluntary and Nonprofit Organizations, 28(6), 2469-2497.

Doherty, B., Haugh, H., \& Lyon, F. (2014). Social enterprises as hybrid organizations: A review and research agenda. International Journal of Management Reviews, 16(4), 417-436.

Dorst, K., \& Cross, N. (2001). Creativity in the design process: Co-evolution of problem-solution. Design Studies, 22(5), 425-437.

Emerson, J. (2008). Visualizing information for advocacy. Tactical Technology Collective. http://www.schrockguide.net/uploads/3/9/2/2/392267/infodesign.pdf February, 28, 2013.

Eppler, M. J., \& Bresciani, S. (2013). Visualization in management: From communication to collaboration. A response to zhang. Journal of Visual Languages and Computing, 24(2), 146-149.

Eppler, M. J., \& Platts, K. W. (2009). Visual strategizing: The systematic use of visualization in the strategic-planning process. Long Range Planning, 42(1), 42-74.
Espinozaa, C. C., \& Cataldob, A. C. (2019). Estudio longitudinal del proceso de adopción de un sistema tipo-ERP usando mapas mentales. Multidisciplinary Business Review, 12(2), 29-54,

Few, S. (2006). Information dashboard design: The effective visual communication of data. O'Reilly Media.

Flockhart, A. (2005). Raising the profile of social enterprises: The use of social return on investment (SROI) and investment ready tools (IRT) to bridge the financial credibility gap. Social Enterprise Journal, 1(1), $29-42$.

Gravoso, R. S., \& Stuart, T. H. (2000). Upland farmers' comprehension of pictorial messages on environmental protection. Journal of Applied Communication, $8(3)$.

Horn, R. E. (1998). Visual language. Global Communication for the 21st Century. Macro VU.

Hynes, B. (2009), Growing the social enterprise - issues and challenges. Social Enterprise Journal, 5(2), 114-125.

Kelton A. S., Pennington R. R., \& Tuttle, B. M. (2010). The effects of information presentation format on judgment and decision making: A review of the information systems research. Journal of Information Systems, 24(2), 79-105.

Leadbeater, C. (1997) The rise of the social entrepreneur. Demos.

Lewis, V. L., \& Churchill, N. C. (1983). The five stages of small business growth. Harvard Business Review, 61(3), 30-50.

London, T., Anupindi, R., \& Sheth, S. (2010). Creating mutual value: Lessons learned from ventures serving base of the pyramid producers. Journal of Business Research, 63(6), 582-594.

López-Gonzáleza, E., Sosa-Varelab, J. C., Ortiz-Sotoc, M., \& Dones-Gonzálezd (2016). El servicio al cliente como estrategia de lealtad para las empresas sociales. Multidisciplinary Business Review, 9(2), 1-9.

Mair, J., \& Sharma, S. (2012). Performance measurement and social entrepreneurship. In C.K. Volkmann, K.O. Tokarski and K- Ernst (Eds.) Social Entrepreneurship and Social Business. An Introduction and Discussion with Case Studies (p.175-189). Springer Gabler.

Mair, J. \& Noboa, E. 2003. The emergence of social enterprises and their place in the new organizational landscape (Working Paper 523). IESE Business School, University of Navarra.

McGrath, L., Bresciani, S., \& Eppler, M. J. (2016). We walk the line: Provisional icon appearance on virtual whiteboards triggers elaborative dialogue and creativity. Computers in Human Behavior, 63, 717--726. 
Meyer, R. E., Höllerer, M. A., Jancsary, D., \& Van Leeuwen, T. (2013). The visual dimension in organizing, organization, and organization research: Core ideas, current developments, and promising avenues. Academy of Management Annals, 7(1), 489-555.

Millar, R., \& Hall, K. (2013). Social return on investment (SROI) and performance measurement: The opportunities and barriers for social enterprises in health and social care. Public Management Review, 15(6), 923-941.

Mittelman, R., \& Rojas-Méndez, J. I. (2013). Exploring consumer's needs and motivations in online social lending for development. Journal of Nonprofit \& Public Sector Marketing, 25(4), 309-333.

Muñoz, C. A., Mosey, S., \& Binks, M. (2011). Developing opportunity-identification capabilities in the classroom: Visual evidence for changing mental frames. Academy of Management Learning \& Education, 10(2), 277-295.

Neher, K. (2013). Visual social media marketing: Harnessing images, Instagram, infographics, and Pinterest to grow your business online. Boot Camp Publishing.

Organizational Research Services (2004). Theory of change: A practical tool for action, results and learning. Annie E. Casey Foundation.

Osterwalder, A., \& Pigneur, Y. (2010). Business model generation: A handbook for visionaries, game changers, and challengers. Wiley.

Papi-Thornton, D. (2016). Tackling heropreneurship: Why we need to move from "the social entrepreneur" to social impact. Stanford Social Innovation Review Online , Feb. 23. Accessed on 11/11/2020 at https:// ssir.org/articles/entry/tackling heropreneurship.

Paschen, J. (2017). Choose wisely: Crowdfunding through the stages of the startup life cycle. Business Horizons, 60(2), 179-188.

Perrini F., \& Vurro C. (2006). Social entrepreneurship: Innovation and social change across theory and practice. In Mair J., Robinson J., \& Hockerts K. (Eds.), Social Entrepreneurship. Palgrave Macmillan.

Pfister, R. A., \& Eppler, M. J. (2012, July). Paths to success: A sketch-based creativity technique for individuals and teams. In IEEE Proceedings of the 16th International Conference on Information Visualisation ( $\mathrm{pp}$. 337-342).
Phaal, R., Farrukh, C. J., \& Probert, D. R. (2004). Technology roadmapping - a planning framework for evolution and revolution. Technological Forecasting and Social Change, 71(1-2), 5-26.

Prahalad, C. K. (2006). The fortune at the bottom of the pyramid. Pearson Education India.

Ridley-Duff, R., \& Bull, M. (2019). Understanding social enterprise: Theory and practice (3rd Edition). Sage.

Seelos, C., \& Mair, J. (2007). Profitable business models and market creation in the context of deep poverty: A strategic view. The Academy of Management Perspectives, 21(4), 49-63. 2007.

Shepherd, D. A. (2020). COVID 19 and entrepreneurship: Time to pivot? Journal of Management Studies. Online first.

Snodgrass, J. G., \& Vanderwart, M. A. (1980). Standardized set of 260 pictures: Norms for name agreement, image agreement, familiarity, and visual complexity. Journal of Experimental Psychology: Human Learning and Memory, 6 (2), 174-215.

Sparviero, S. (2019). The case for a socially oriented business model canvas: The social enterprise model canvas. Journal of Social Entrepreneurship, 10(2), 232-251.

Tufte, E.R. (1997). Visual explanations. Images and quantities, evidence and narrative. Graphic Press.

Tversky, B., \& Suwa, M. (2009). Thinking with sketches. In A. B. Markman \& K. L.Wood (Eds.), Tools for Innovation. Oxford University Press.

Vessey, I. (1991). Cognitive fit: A theory-based analysis of the graphs versus tables literature. Decision Sciences, 22, 219-240.

Virzia, N., Koiralab, B., \& Spillanc, J.E. (2015). Factors that influence university students' inclination to become an entrepreneur: Insights from guatemala. Multidisciplinary Business Review, 8(2), 72-84.

Yakura, E. K. (2002). Charting time: Timelines as temporal boundary objects. Academy of Management Journal, 45(5), 956-970.

Yunus, M. (2009). Creating a world without poverty: Social business and the future of capitalism. Public Affairs. 